\title{
Forum
}

\section{Without fear or favour}

An open letter to my colleagues in journalism education:

$\mathrm{I}^{\mathrm{T}}$

T HAS been the greatest pleasure of my working life to have come to know you all as fellow travellers in the cause of journalism education. But, then again, if you have spent 10 years doing something, it had better be particularly significant in your life or you have, well, wasted your time.

We have dealt with a lot of change over the past decade - some of it good and, indeed, overdue. The unit standards have given us a national curriculum and a simple set of criteria that help guide newbies in the business of journalism training. The debate as to whether unit standards tend to help training (via their curriculum function) or hinder it (e.g. by forcing us to over-assess students) is not yet resolved. However, on balance I think they have helped us all a great deal.

However, the changes have not stopped there. Polytechnics have tightened up their own regimes, making their own demands of journalism teachers in terms of internal report- ing procedures, restructurings, etc. Universities have now entered the fray bigtime, i.e. the Wellington Polytechnic takeover, Auckland Institute of Technology's redesignation as Auckland University of Technology. The Tertiary Education Commission (TEC) has sent a nasty shock through everyone's lives, placing greater emphasis on increasing research outputs. Rather than lessening with the years, the pressure on journalism educators has, if anything,become greater. I sometimes wonder why we do it.

So, why do we do it. Until very recent times, when I personally have come to feel that I should move along, I have found teaching to be the most fantastic job possible - and teaching journalism to be the icing on top of the teaching cake. The chance to live vicariously through my students' stories and workplace interactions, the chance to speak with a wide range of media people, the chance to share ideas with like-minded, talented folks, like yourselves, has been truly wonderful. I have been able to hold forth on all manner of subjects without having to take responsibility for actually doing any journalism. 
Alas, those days are over. By the time you hear this I will have had enough time at Radio New Zealand to make a complete prat of myself. Here's hoping I haven't done that. Here's hoping that 10 years of teaching has made me a better journo. It certainly should have done that. Here's also hoping that my $\mathrm{PhD}$ grinds through to a successful conclusion, too, so that I will be suitably qualified should I ever wish to teach again. I must say that I am a little concerned that my lack of an MA would mean that were I to apply for a teaching job at Massey University today I would have to be excluded due to lack of qualifications.

Anyway, here's to you all, to all your support over the years, to all your efforts on behalf of those who want to be journalists, to all the times you've fretted about a student story that's gone pear-shaped, or about a student who's struggled, to all those times you've tried to explain to your bosses just what it is that makes journalism education different. You are a model of how industry training-based education should work.

I feel I should offer a couple of closing challenges (especially since I will no longer bear any direct responsibility for implementing them with students). I heard someone on National Radio's MediaWatch programme a few months ago lamenting the lack of diversity in newsrooms. $\mathrm{He}$ pointed the finger at training courses, which he saw as turning out too many smart, well-bred Pakeha youngsters. The point was, I feel, well made. I was very happy to see that it came from a provincial chief reporter and not an academic - a reminder that the industry does have some values that we can respect. We need to ensure that we do not turn journalism education into an elite field where a degree becomes essential (says he who has done his fair share to make this unwelcome situation come about - mea culpa).

The central tenets of journalism also need to be repeated to students: that journalism is about 'comforting the afflicted and afflicting the comfortable' and about reporting 'without fear or favour'. I recently heard author James McNeish talking about Kiwi journalist (and Rhodes Scholar) Geoffrey Cox. Cox, as a very young man, went to war-torn Spain in 1937 and to the frontline of the SovietFinnish Winter War in 1940.

I am reminded of Peter Arnett, the Southern Boy who had an instinct for finding the frontline in any conflict. What these old hacks tell us is that journalism is about finding the story. You can teach facts and theory all day long, and you can tick off all the unit standards boxes as each performance criterion and element of 
THE PUBLIC RIGHT TO KNOW

learning is achieved, but you cannot make someone into a journalist unless they possess those old-fashioned qualities that we value so much: a nose for a good story, a sincere interest in what makes people do what they do, a feeling of outrage when someone gets the shaft, and an idealistic vision that things should simply be better for people. Cynicism is THE worst attribute a journalist can have.

And, in the spirit of Cox and Arnett, a journalist should have an instinct for the frontline. When a story breaks a good reporter wants to be on the scene (e.g. land occupations, Aramoana). When a big issue breaks a good reporter wants to get his or her hands dirty and open up the whole can of worms by talking to those in the front ranks. Repeating the predictable offerings of politicians and the Usual Suspects is, basically,crap. It ain't journalism. Rather, it's a kind of PR.

As a final comment, I can only say that I hope I myself have been listening to what I've just been telling you.

Fond memories and sincere regards,

\section{David Venables \\ Wellington}

New Zealand

DavidVenables isformer Head of School, Journalism, at Massey University and outgoing president of the Journalism Education Association of New Zealand. This open letter was read to delegates at the Jeanz annual conference in New Plymouth, 4-5 December 2003.

Fiji's 'embedded journalists' Dr Tupeni Baba's speech at the relaunch of Pacific Journalism Review, 3 October 2003.

$\Upsilon \begin{gathered}\text { HANK you for your invitation to } \\ \text { be your guest at the re-launching }\end{gathered}$ of the Pacific Journalism Review journal. I must acknowledge the presence of the editor of the Listener, Finlay Macdonald, and note that the first time I became aware of his journal was back in 1987, when it devoted a whole issue to the Bavadra Government.

I am not sure whether that particular issue came out while we were still in Government, or whether it actually came out after we were pushed out in the Rabuka coup on May 14 that year.

I recall that the only other time I featured in that magazine was in 2002 , on coming to the University of Auckland. And the point of interest, I guess for the Listener, was that I was again thrown out of Government by another coup - or attempted coup - of George Speight and incarcerated in the Fiji Parliament for some 56 days.

There was some implication in 